\title{
Covid-19 and Mental Health of the Public
}

\author{
Notsonu Toba Angami Khatso ${ }^{1}$, Manju Chandankhede ${ }^{2}$ and Swarupa Chakole ${ }^{3}$ \\ ${ }^{1}$ First Year Student Datta Meghe Medical College, Nagpur, India \\ ${ }^{2}$ Department of Biochemistry Datta Meghe Medical College, Shalinitai \\ Meghe Hospital and Research Centre, Nagpur, India \\ ${ }^{3}$ Department of Community Medicine Jawaharlal Nehru Medical College, Datta \\ Meghe Institute of Medical Sciences Sawangi (Meghe), Wardha, India \\ Corresponding author email:drmanjusc@gmail.com
}

\section{ABSTRACT}

Psychological well-being concerns and treatment for the most part assume a lower priority when the restricted assets are intended for pandemic control. In this worldwide philanthropic emergency of the Coronavirus pandemic, psychological well-being issues have been accounted for from all over the world. Corona virus 2019 (COVID-19), a respiratory disease caused by a new corona virus (SARS corona virus 2, also known as novel corona virus), has spread throughout China and has attracted worldwide attention. The WHO declared the COVID-19 outbreak a global public health emergency on January 30, 2020. Following the outbreak of the Corona virus syndrome (SARS-Corona Virus) in 2002, the arrival of SARS 2 HIV, along with MERS Corona Virus of 2012, the third most common introduction of the 20th century of the worst corona and most often infected in humans. Covid-19 is a sign of a mental state and a source of physical health problems. Reducing the harmful impact of Covid-19 on mental health is of paramount importance to the international community.

\section{KEY WORDS: COVID-19, CORONA VIRUS, MENTAL HEALTH, GENERAL POPULATION AND PREVALENCE.}

\section{INTRODUCTION}

Coronavirus (COVID-19) is a highly contagious disease caused by a highly contagious respiratory disease coronavirus 2 (SARS-CoV-2) that spreads rapidly from person to person worldwide. It first appeared in Wuhan, China, in early December 2019, and the World Health Organization declared Europe a hotbed of the epidemic on March 13, 2020. The number of patients in many European countries and the United States has risen, and the death toll in Italy exceeds that of China.1 The next wave of viruses, with great destructive power, seems to be designed for Africa and Latin America. Unfortunately, many countries have failed to follow

Biosc Biotech Res Comm P-ISSN: 0974-6455 E-ISSN: 2321-4007

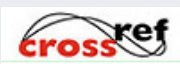

Identifiers and Pagination

Year: 2021 Vol: 14 No (7) Special Issue

Pages: 60-62

This is an open access article under Creative

Commons License Attribn 4.0 Intl (CC-BY). DOI: http://dx.doi.org/10.21786/bbrc/14.7.14
WHO's clear recommendations for content, including a comprehensive test (test, test, test "every case suspects), a case of segregation, prosecution, and community eradication, all of which are fundamental to public health and infectious diseases.

Patients with pneumonia caused by the latest corona virus (covid19) were recorded in the Chinese city of Wuhan in December 2019. SARS-Cov-2, the causative virus, was found to be a 79\% coronavirus novel gene SARS- Cov since the SARS outbreak in 2003.3 The virus quickly spread worldwide, prompting the WHO to call the pandemic a global epidemic on March 11, 2020. There are 150 million active cases worldwide, with 3.15 million deaths. Fever, fatigue, sore throat, loss of smell and taste are all symptoms of coronavirus infection, which can lead to heart and respiratory failure, acute respiratory syndrome, or even death in severe cases. COVID-19 can have a worse effect on human mental health than its physical effects.

\section{Article Information}

Received: $16^{\text {th }}$ April 2021 ccepted after revision: $05^{\text {th }}$ June 2021 
Suicide and mental illness are expected to rise due to the uncertainty and fear of the virus, as well as mass confinement and economic downturns. People's mental health has been shown to be severely affected during times of illnesses such as SARS, based on previous experience. 5 During the SARS epidemic, for example, people were found to have high levels of stress, depression, and anxiety. Individuals who were isolated during SARS reported an undiagnosed level of mental illness, according to one study. 6 All tests that looked at psychological problems during the Coronavirus epidemic showed that those affected did not show any signs of depression. Coronavirus can affect the psychological well-being of people at various levels of society, from infected patients and medical staff to families, children, students, patients with unstable behaviors, and even specialists in various fields, due to its spread, rapid spread, and high mortality rate.

\section{DISCUSSION}

In the midst of the Covid 19 epidemic, this study looked at human mental health and its predictable evolution. Compared with the increase before the epidemic, there was a significant increase in the types of unfriendly psychological consequences for most people. People's mental health varies depending on the type of disease, government readiness, availability of resources / facilities, and adequate distribution of Covid-related information in different regions.8 People watching Covid 19 news have a lot of concerns, according to a study. For many people, cheating and stories made about covid 19 will exacerbate symptoms of depression. Nations with covid-19 problem have more psychological consequences for people in less developed and developing countries, as these countries still suffer from the death toll from other infectious diseases. Women are more likely to be depressed, depressed, and post-traumatic stress disorder (PTSD) than men, according to a study.

While growth increases the risk of Coronavirus infection and death, the results of current studies show that during epidemics, levels of anxiety, sadness, and stress are all higher in the 21-40 year age group.10,11 According to research, poor economic conditions, lack of education, and unemployment are all significant risk factors for developing symptoms of depression, especially depression. In addition, people with at least one family member, parent, or partner with Coronavirus positive have a much higher rate of anxiety.12 It was also found that symptoms of psychiatric side effects were more common at the beginning of the show, when people were tested for necessary isolation, unexpected dysfunction, and insecurity associated with outbreaks. At present, people with a mental, psychiatric, or substance abuse condition are at risk of SARS-COV-2 infection and may be at greater risk for serious side effects, including death. People are mobilized and forced to take precautionary measures when they are worried and fearful of emergence.
Related studies on mental health were reported. Rakshale et. al. reported about efficacy of self help- mental health promotion model on mental health of care givers 16 . Shaheed et. al. reported on Quality of Life and Mental Status in Cancer Patients17. Gawai et. al. reported on on impact of covid 19 and mental health. Other related studies on mental health were reviewed.

\section{CONCLUSION}

This fundamental review analyzed the mental status of the overall population in this current Covid-19 pandemic and focused on the related danger factors. A high predominance of antagonistic mental side effects were accounted for in many investigations. Psychological well-being issues should be considered all together for proper projects and methodologies to be created. Course and approaches should be established to successfully work with the weight of emotional well-being.

\section{REFERENCES}

Anand $\mathrm{Kb}$, Karade S, Sen S, Gupta Rm. SarsCov-2: Camazotz's Curse. Med J Armed Forces India. 2020 Apr;76(2):136-141. Doi: 10.1016/J. Mjafi.2020.04.008. Epub 2020 Apr 27. Pmid: 32341622; Pmcid: Pmc7183968.

Cao W, Fang Z, Hou G, Han M, Xu X, Dong J, Zheng J. The Psychological Impact Of The Covid-19 Epidemic On College Students In China. Psychiatry Res. 2020 May;287:112934. Doi: 10.1016/J.Psychres.2020.112934. Epub 2020 Mar 20. Pmid: 32229390; Pmcid: Pmc7102633.

Gaidhane, Abhay M., Anju Sinha, Mahalaqua Nazli Khatib, Padam Simkhada, Prakash B. Behere, Deepak Saxena, Bhaskaran Unnikrishnan, Mahafroz Khatib, Mahjabeen Ahmed, And Zahiruddin Quazi Syed. "A Systematic Review On Effect Of Electronic Media On Diet, Exercise, And Sexual Activity Among Adolescents." Indian Journal of Community Medicine 43, No. S (December 2018): 56-65. Https://Doi.Org/10.4103/Ijcm. Ijcm_143_18.

Gao J, Zheng P, Jia Y, Chen H, Mao Y, Chen S, Wang Y, Fu H, Dai J. Mental Health Problems And Social Media Exposure During Covid-19 Outbreak. Plos One. 2020 Apr 16;15(4):E0231924. Doi: 10.1371/Journal. Pone.0231924. Pmid: 32298385; Pmcid: Pmc7162477. Gawai, Jaya Pranoykumar, Seema Singh, Vaishali Deoraoji Taksande, Tessy Sebastian, Pooja Kasturkar, And Ruchira Shrikant Ankar. "Critical Review On Impact Of Covid 19 And Mental Health.” Journal of Evolution Of Medical And Dental Sciences-Jemds 9, No. 30 (July 27, 2020): 2158-63. Https://Doi.Org/10.14260/ Jemds/2020/470.

González-Sanguino C, Ausín B, Castellanos Má, Saiz J, López-Gómez A, Ugidos C, Muñoz M. Mental Health Consequences During The Initial Stage Of The 2020 Coronavirus Pandemic (Covid-19) In Spain. Brain 
Behav Immun. 2020 Jul;87:172-176. Doi: 10.1016/J. Bbi.2020.05.040. Epub 2020 May 13. Pmid: 32405150; Pmcid: Pmc7219372.

Hawryluck L, Gold Wl, Robinson S, Pogorski S, Galea S, Styra R (2004 Jul). Sars Control And Psychological Effects Of Quarantine, Toronto, Canada. Emerg Infect Dis;10(7):1206-12. Doi: 10.3201/Eid 1007.030703. Pmid: 15324539 ; Pmcid: Pmc3323345.

Mcalonan Gm, Lee Am, Cheung V, Cheung C, Tsang Kw, Sham Pc, Chua Se, Wong Jg (2007 Apr). Immediate And Sustained Psychological Impact of An Emerging Infectious Disease Outbreak On Health Care Workers. Can J Psychiatry;52(4):241-7. Doi: 10.1177/070674370705200406. Pmid: 17500305.

Miro Jakovljevic, Sarah Bjedov, Nenad Jaksic \&t Ivan Jakovljevic (2020). Covid-19 Pandemia And Public And Global Mental Health From The Perspective Of Global Health Security. Psychiatria Danubina;32(1):6-14.

Patil, Manoj, Shital Telrandhe, Mahalaqua Nazli Khatib, Shilpa Gaidhane, Deepak Saxena, Pankaj Bhardwaj, Bhaskaran Unnikrishnan, Abhay M. Gaidhane, And Zahiruddin Quazi Syed (April 20, 2020). Stimulating Home Environment For Early Childhood Development By Household Play Materials For Under 5 Rural Children In Forest Buffer Zone Of Wardha District." Journal Of Evolution Of Medical And Dental SciencesJemds 9, No. 16: 1336-40. Https://Doi.Org/10.14260/ Jemds/2020/291

Rakesh Kumar Jha, Pradip Jain, Ranjit S. Ambad, Nandkishor (2020). The Origin, Transmission And Mortality Of Corona Virus. Jcr;7(10):93-96. Doi:10.31838/ Jcr.07.10.23

Rakshale, Nilima, Tessy Sebastian, Seema Singh, And Pradip Patil (2020). Efficacy Of Self Help- Mental Health Promotion Model On Mental Health Of Care Givers Of Mentally Ill - Pre Experimental Study.” International Journal Of Modern Agriculture 9, No. 3: 46-52.

Raut, Arati, Ruchira Ankar, And Sheetal Sakharkar (November 2020). The Poor And The Pandemic: Covid-19." Journal of Clinical And Diagnostic Research 14, No. 11: Le7-9. Https://Doi.Org/10.7860/ Jcdr/2020/45425.14248.

Salari N, Hosseinian-Far A, Jalali R, Vaisi-Raygani A, Rasoulpoor S, Mohammadi M, Rasoulpoor S, KhalediPaveh B. Prevalence Of Stress, Anxiety, Depression Among The General Population During The Covid-19 Pandemic: A Systematic Review And Meta-Analysis.
Global Health. 2020 Jul 6;16(1):57. Doi: 10.1186/ S12992-020-00589-W. Pmid: 32631403; Pmcid: Pmc7338126.

Salari N, Hosseinian-Far A, Jalali R, Vaisi-Raygani A, Rasoulpoor S, Mohammadi M, Rasoulpoor S, KhalediPaveh B (2020 Jul). Prevalence Of Stress, Anxiety, Depression Among The General Population During The Covid-19 Pandemic: A Systematic Review And Meta-Analysis. Global Health. 6;16(1):57. Doi: 10.1186/ S12992-020-00589-W. Pmid: 32631403; Pmcid: Pmc7338126.

Shaheed, Raza, Samarth Shukla, Sourya Acharya, Uplabdh Gopal, And Neema Acharya (August 2019). Journey From Fighters To Survivors: Quality Of Life And Mental Status In Cancer Patients In A Rural Tertiary Care Hospital." Journal Of Clinical And Diagnostic Research 13, No. 8: Xc1-4. Https://Doi.Org/10.7860/ Jcdr/2019/41982.13065.

Spoorthy, Mamidipalli Sai, Sree Karthik Pratapa, And Supriya Mahant (June 2020). Mental Health Problems Faced By Healthcare Workers Due To The Covid-19 Pandemic-A Review.” Asian Journal Of Psychiatry 51. Https://Doi.Org/10.1016/J.Ajp.2020.102119.

Talevi D, Socci V, Carai M, Carnaghi G, Faleri S, Trebbi E, Di Bernardo A, Capelli F, Pacitti F (2020 May-Jun). Mental Health Outcomes Of The Covid-19 Pandemic. Riv Psichiatr;55(3):137-144. Doi: 10.1708/3382.33569. Pmid: 32489190.

Talevi D, Socci V, Carai M, Carnaghi G, Faleri S, Trebbi E, Di Bernardo A, Capelli F, Pacitti F (2020 May-Jun). Mental Health Outcomes Of The Covid-19 Pandemic. Riv Psichiatr; 55(3):137-144. Doi: 10.1708/3382.33569. Pmid: 32489190.

Torales J, O'higgins M, Castaldelli-Maia Jm, Ventriglio A (2020 Mar 31). The Outbreak of Covid-19 Coronavirus And Its Impact On Global Mental Health. Int J Soc Psychiatry. 2020 Jun;66(4):317-320. Doi: 10.1177/0020764020915212. Epub. Pmid: 32233719.

Vindegaard N, Benros Me. Covid-19 Pandemic And Mental Health Consequences: Systematic Review of The Current Evidence. Brain Behav Immun. 2020 Oct;89:531-542. Doi: 10.1016/J.Bbi.2020.05.048. Epub 2020 May 30. Pmid: 32485289; Pmcid: Pmc7260522. Xiong,J., Phan.L., Nasri.F., et al., (2020) Impact Of Covid-19 Pandemic On Mental Health In The General Population: A Systematic Review,Journal of Affective Disorders, Volume 277, 